\title{
Narrative journalism as complementary inquiry
}

\author{
Jorgen Jeppesen \& Helle Ploug Hansen
}

\begin{abstract}
Narrative journalism is a method to craft stories worth reading about real people. In this article, we explore the ability of that communicative power to produce insights complementary to those obtainable through traditional qualitative and quantitative research methods. With examples from a study of journalistic narrative as patient involvement in professional rehabilitation, interview data transcribed as stories are analyzed for qualities of heterogeneity, sensibility, transparency, and reflexivity. Building on sociological theories of thinking with stories, writing as inquiry, and public journalism as ethnography, we suggest that narrative journalism as a common practice might unfold dimensions of subjective otherness of the self. Aspiring to unite writing in both transparently confrontational and empathetically dialogic ways, the narrative journalistic method holds a potential to expose dynamics of power within the interview.
\end{abstract}

Keywords: narrative journalism, complementarity, heterogeneity, common practice, interview data

Please cite this article as:

Jeppesen, J. \& Hansen, H.P. (2011). Narrative journalism as complementary inquiry. Qualitative Studies, 2(2): 98-117.

\section{Introduction}

Narrative journalists often compare themselves to anthropologists. Walt Harrington, using the term intimate journalism, lists anthropology in the genealogy of this genre and calls on its practitioners to seek inspiration in qualitative social science (Harrington, 1997, p. xvii). In parallel with the obligation of the sociologist and anthropologist, it is the duty of the intimate journalist to place him or herself in a position and state that allows one to hear what the person says, thinks, and believes, he argues (Harrington, 1997, p. xxxii). Mark Kramer finds that narrative journalism relates to the life lived, resembling anthropological and ethnographic sciences only with artistic effects (Jørgensen, 2007, p. 38).

Some qualitative researchers affirm that social science is not the same as journalism, because journalism must not make explicit its procedures for editing and analysis (Tanggaard and Brinkmann, 2010, p. 511). The eligibility of journalism within social science is due solely to the application of its communicative power, they state.

In this article, we reflect on narrative journalism as a method of inquiry that produces knowledge by way of the very potential of communicative power. Insights complementary to those of traditional scientific research, quantitative as well as qualitative, are created, we claim, by virtue of the presentational power of publicity of the non-fictitious text narrating its characters as non-anonymous subjects. As recognized with the idea of complementarity, methods might be mutually exclusive, but separately necessary for the understanding of a phenomenon ${ }^{1}$. In support of our assumption, we present findings from an empirical study.

Twenty years ago the first author of this article was employed as a professional journalist in a disability organization. His and his colleagues' job was to write stories about people with a 
lifelong impairment, and their close relatives. The stories, internally labeled 'The Good Narrative", was a subject of professional reflection among the editorial staff, not least what made them different from stories with similar - or the same - people in the mass media. By carefully avoiding pity, sensationalism, hero worship, or just role modeling, 'our' disability journalistic story sought to bring out deviation as heterogeneity, equal to variation as diversity among the non-disabled, both constituting the same, namely subjective otherness. This otherness was an individuality in which impairment was one of numerous circumstances, rarely the predominant one yet indispensable for the story. At the same time these stories were conceived and received within organizational contexts of the membership community, shaping significant practices of how to live with the disease. They became stories of heterogeneity in common.

This notion of a narrative heterogeneity in common connects to scholarly efforts of studying relations between narrative, self and social practice. As one such effort asks:

Meaning itself $[\ldots]$ is not pre-ordained by an abstract or ahistorical system of terms but is emergent in the concrete, everyday activities of individuals and communities. This dynamic picture of social life raises new questions. Precisely how, that is, through what kinds of common practices, do humans create, resist and modify their social worlds and their own identities? (Mattingly, Jensen and Throop, 2009, p. 6)

A multitude of concepts have been listed: narrative, power, complementarity, heterogeneity, self, social practice, meaning, activities, individuals, communities, social life, common practices, create-resist-modify, social worlds, identities. To grasp the complexity between these occurrences, we suggest a conceptualization evolving from Arthur Frank's idea about 'thinking with stories' (Frank, 2004a), Laurel Richardson's and Elizabeth Adams St. Pierre's work on 'writing as inquiry' (Richardson and St. Pierre, 2005), and Norman Denzin's precept for the 'performance ethnography' (Denzin, 2003). From different perspectives, these sociologists have in common both a theoretical and practical interest in narrative as a method of research linking process with power.

In the following, we will present key concepts of their thinking with the purpose of creating an analytical strategy to discuss the research question: How can journalistic narrative as a common public performance be a method of inquiry producing complementary insight?

\section{Conceptualizing Heterogeneity in Common}

Moral non-fiction

According to Frank, the story does not have any hidden meaning that needs decoding. "I do not analyze these stories. I advocate trying to think with them, a process closer to letting the stories analyze us", says Frank (2004a, p. 6), who proposes 'moral nonfiction' as a name for the genre. Analyzing, i.e. to think about as opposed to think with, is to reduce, to finalize the protagonist to a category. The literary character - or the medical patient and his suffering - can never fully be understood, because a person's otherness is not a container from which we can draw psychological, cultural or physical attributes. Thinking with the story is to balance in a constant tension between merger and separation. 
Dialogue is the complementarity of merging and separating: orienting your voice to others, merging with those other voices, then separating again, and never finalizing this process. Alterity remains in tension with the desire to merge with the other. The heroic task is to live with tension, perpetually seeking balance. This balance solves but never resolves; it is never a finalized solution. What is solved is how to keep the tension within the bounds of dialogue - to keep dialogue open. (Frank, 2004a, p. 133)

Frank wants to delimit representation. Something must be left unresolved, silent and untold, he understands, because it leaves you open to recognize and relate to what you do not understand. Exhaustive description is at best an illusion only².

Process and product

Using the term Creative Analytical Practices (CAP), Richardson and St. Pierre widen the scope of what can be regarded as data, as representation, and in consequence the criteria of validity. CAP ethnographers can learn about their topics and themselves; about that which was left unknowable and unimaginable using conventional analytical procedures and writing formats (Richardson and St. Pierre 2005, p. 963). They demonstrate the writing process and the writing product as deeply intertwined; the product cannot be separated from the producer, the mode of production, or the method of knowing. And how the author positions the self as knower and teller becomes crucial.

They sum up five criteria: substantive contribution to our understanding of social life; aesthetic merit; reflexivity; impact on the reader; expression of a reality. And they locate one of the origins of CAP in journalism, more specifically in the school of New Journalism of the sixties and seventies, with the writer - much like the modern auto-ethnographic self - being on stage in her story of the story (Richardson and St. Pierre, 2005, p. 926).

\section{Performing journalism}

Narrative theory and method have become part of most qualitative research handbooks, but they seldom include the tradition of narrative journalism. One exception is Denzin, who speaks in favor of a "public-journalism-as-ethnography" (Denzin, 2000, p. 901). He sees two versions of new journalistic writing: ethnographic realism and cultural phenomenology, the former displaying a social world in rich detail, the latter describing what it feels like to be present in such a world (Denzin, 1997, pp. 126-162). Reality is anchored in the text itself, challenging readers to read reflexively, mirroring readers' process of self-formation and self-understanding, and Denzin, arguing that these forms of textual constructions undo old dichotomies between journalism and science, literature and ethnography, fact and fiction, encourages ethnographers not to stick to structural dissection, but engage in learning how to write stories.

Denzin advocates a writer fusing intimate and civic journalism, creating stories that enable changes in the public and private spheres of everyday life. It is a narrative writer, who can fulfill a pressing need for the invention of a reflexive writing form in which the narration is not simply a record of human experience, but also a method that empowers the reader (Denzin, 2000, pp. 900-903). 
The reflexive, interacting, interview format is a forerunner of the performative interview with which researchers are increasingly performing culture because they write it. According to Denzin, a previous boundary between performativity ("doing") and performance ("done") has disappeared, and he lists various forms of personal performance narratives such as the personal experience story, the self story; the personal story; testimonial. These are didactic forms of narrative, which entertain, direct, maintain and reproduce institutions and discourses in and across generations. Four, explicitly journalistic, standards of performative criteria must be met: Accuracy, non-maleficence, the right to know, show one's moral colors (Denzin, 2003).

\section{Transparent presence}

Ethically, the insistence on the transparent presence of a perceptible 'social scientific self' is evident with these three narrative theorists. They seem to activate immanent moral implications as inseparable and fruitful parts of the researching process: Frank by accentuating the mutuality of generosity, Richardson by qualifying the personal in and of writing as thinking, and Denzin by emphasizing the commonality of researcher and researched. To expose the construction of knowledge they motivate researchers to exhibit textually how they incorporate that mutuality, personality, and commonality.

The affinity to narrative journalism centers on this textual exhibition. By exposing the use of language as personal and subjective, the narrative journalist incorporates the method of writing as part of the story. He stories the way of telling, thereby making room for the characters to be other than an object, and for readers to know how that happens.

When applying telling as a way of knowing, 'the how' becomes of paramount importance, how 'the what' is told. And when qualitative research might be empowered by importing the good story (Frank, 2004b), we attempt to go the other way round by importing analysis. By formulating analytical questions grounded in narrative theory, we want to examine how the journalistic story might know.

\section{True writing}

Our analytical strategy began with a search for determinations with Frank, Richardson, and Denzin of what indicates true writing ${ }^{3}$. By extracting and systematizing key concepts regarding what can be understood as true writing, and what cannot, we built, across their thinking, categories of authenticity and unreliability. Finally, on this synthesis of determinations, we laid down criteria for the complementary journalistic narrative.

Key concepts identified as indicators of authenticity and unreliability, respectively, were categorized (Table 1). Authenticity indicators were grouped in five categories: Heterogeneity; Change; Sensibility; Transparency; and Reflexivity. Unreliability indicators were grouped in three categories: Emotionalism; Neutrality; and Superior Knowledge.

Finally, the authenticity categories were combined crosswise in three positive criteria phrased as analytical questions:

1. How does the writing make room for heterogeneity?

2. How does the story instigate change?

3. How does the author position himself? 
And the unreliability categories were combined in one negative criterion phrased as the analytical question:

4. How does the author balance between humility and paternalism?

Authenticity and unreliability categories derived from true writing concepts of Arthur Frank, Laurel Richardson/Elizabeth Adam St. Pierre, and Norman Denzin:

\begin{tabular}{|c|c|c|c|c|}
\hline & \multicolumn{4}{|c|}{ True Writing Concepts } \\
\hline \multirow{6}{*}{ 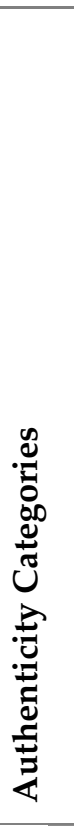 } & & Frank (2004a) & $\begin{array}{l}\text { Richardson/St. } \\
\text { Pierre (2005) }\end{array}$ & Denzin (2003) \\
\hline & Heterogeneity & $\begin{array}{l}\text { A sense of the } \\
\text { other's inner } \\
\text { unfinalizability }\end{array}$ & $\begin{array}{l}\text { How to document } \\
\text { becoming }\end{array}$ & $\begin{array}{l}\text { Interviewing } \\
\text { another is a } \\
\text { privilege granted }\end{array}$ \\
\hline & Change & $\begin{array}{l}\text { One story calls forth } \\
\text { another story }\end{array}$ & $\begin{array}{l}\text { Generate new } \\
\text { questions }\end{array}$ & $\begin{array}{l}\text { Take public action } \\
\text { on private troubles }\end{array}$ \\
\hline & Sensibility & $\begin{array}{l}\text { A space of } \\
\text { consolation }\end{array}$ & $\begin{array}{l}\text { Affect me } \\
\text { emotionally or } \\
\text { intellectually }\end{array}$ & $\begin{array}{l}\text { Create moral } \\
\text { compassion }\end{array}$ \\
\hline & Transparency & $\begin{array}{l}\text { A new relation of } \\
\text { author to character }\end{array}$ & $\begin{array}{l}\text { The self as knower } \\
\text { and teller }\end{array}$ & $\begin{array}{l}\text { Show one's moral } \\
\text { colors }\end{array}$ \\
\hline & Reflexivity & $\begin{array}{l}\text { Instigate self } \\
\text { reflections }\end{array}$ & $\begin{array}{l}\text { Author's } \\
\text { subjectivity both a } \\
\text { producer and a } \\
\text { product of the text }\end{array}$ & $\begin{array}{l}\text { Reader experiences } \\
\text { his own } \\
\text { subjectivity }\end{array}$ \\
\hline \multirow{3}{*}{ 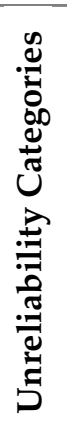 } & Emotionalism & $\begin{array}{l}\text { Unification with the } \\
\text { other }\end{array}$ & $\begin{array}{l}\text { Not demonstrating } \\
\text { a social scientific } \\
\text { perspective }\end{array}$ & Confessional mode \\
\hline & Neutrality & $\begin{array}{l}\text { Extracting static } \\
\text { themes or listing of } \\
\text { characteristics }\end{array}$ & Boring & $\begin{array}{l}\text { Access to a private } \\
\text { self, which is the } \\
\text { real self }\end{array}$ \\
\hline & $\begin{array}{l}\text { Superior } \\
\text { Knowledge }\end{array}$ & Monologue & $\begin{array}{l}\text { The scientific goal } \\
\text { is representation }\end{array}$ & $\begin{array}{l}\text { Certain experiences } \\
\text { are more authentic } \\
\text { than others }\end{array}$ \\
\hline
\end{tabular}

Table 1. 


\section{Chronicles of Life with Amyotrophic Lateral Sclerosis}

Authorizing personal experiences

As part of an ongoing study investigating journalistic narrative as patient involvement in professional multidisciplinary health rehabilitation, Jeppesen writes stories with six people diagnosed with Amyotrophic lateral sclerosis (ALS). The purpose is to develop a method, which authorizes personal experiences as an actively constitutive force in the individual rehabilitation process by voicing views complementary to perceptions of the rehabilitation professionals.

ALS is a rapidly progressive neurodegenerative disease, usually affecting people above 50 years of age and resulting in an extensive need for personal care and assistive devices for mobility and communication. A few years after the diagnosis, those who choose to prolong life must accept permanent ventilator, stomach feeding tube, etc.

Each participant is interviewed four times during one year, and the subsequent story, constructed with methods of intimate and narrative journalism, becomes part of the participant's medical record in the National Rehabilitation Centre for Neuromuscular Diseases. In addition, the story is mailed personally to the significant professionals involved with the participant at hospitals (neurological and respiratory departments), community services, the family general practitioner, etc. Finally, the four stories are published as a narrative chronicle on the website of the national rehabilitation centre.

Purposeful sampling seeking maximum variation with respect to rhetorical capabilities, compliance with professional rehabilitation norms, educational level, occupation, and marital/parental status was applied in recruiting participants. Three women and three men aged 38-62 years were selected.

Initially, a contact letter was sent to participants, transforming the academic study protocol into the following four questions:

1. What can you tell others who develop ALS that might help them?

2. How can the medical and rehabilitation professionals become better at understanding your needs and wishes?

3. How do you opt for or select against life prolonging treatments?

4. What would you tell others who have no knowledge of ALS about the joys and sorrows in your everyday life?

In accordance, the interviews would deal with core complex rehabilitation dilemmas of ALS, such as: How to communicate when loosing the ability to speak; How to live with a ventilator (and a feeding tube, etc) when loosing bodily capabilities; How to accept professional care round the clock when loosing all privacy; How to give and receive love when loosing marital relations; How to avoid loosing parental authority.

Story materials consist of 1 ) verbatim transcription of appropriate selections of voice recordings of the interview conversation, and 2) field notes before, during and after interview. The story is crafted using narrative journalistic techniques of scene, dialogue, symbolic details, informal voice, and digressions (Harrington, 1997; Thorsen, 2003; Kramer and Call, 2007). 
Stories with Hanne Stenmose

In the following, we will analyze excerpts of the four stories with Hanne Stenmose, the first participant included (Jeppesen, 2011). Hanne Stenmose was diagnosed in October 2008, at the age of 49. She is married to Claus, with two adopted children, eight-year-old Thea, and elevenyear-old Mads. Prior to the diagnosis, she worked as a bank clerk. Table 2 gives a brief overview of the stories in relation to her disease progression.

Hanne Stenmose's stories: titles, chronology, topics, and disease progression:

\begin{tabular}{|c|c|c|c|c|}
\hline & Story I & Story II & Story III & Story IV \\
\hline $\begin{array}{l}\text { Title and } \\
\text { date }\end{array}$ & $\begin{array}{l}\text { Worse than the } \\
\text { diagnosis } \\
\text { January } 2010\end{array}$ & $\begin{array}{l}\text { Not only the end of } \\
\text { the world } \\
\text { May } 2010\end{array}$ & $\begin{array}{l}\text { You are allowed to } \\
\text { hope } \\
\text { September } 2010\end{array}$ & $\begin{array}{l}\text { I am here every day } \\
\text { January } 2011\end{array}$ \\
\hline Main topics & $\begin{array}{l}\text { Stemcell } \\
\text { therapy } \\
\text { A journey to } \\
\text { Vietnam }\end{array}$ & $\begin{array}{l}\text { The children } \\
\text { Telling one's } \\
\text { story } \\
\text { Emotional lability }\end{array}$ & $\begin{array}{l}\text { Being a parent } \\
\text { Hope } \\
\text { Rehabilitation }\end{array}$ & $\begin{array}{l}\text { Future life with a } \\
\text { tracheostomy } \\
\text { Creating a memory }\end{array}$ \\
\hline Speech & $\begin{array}{l}\text { Slightly } \\
\text { affected }\end{array}$ & Slightly affected & Medium affected & Strongly affected \\
\hline Ventilator & No & No & Non invasive & Non invasive \\
\hline
\end{tabular}

Table 2.

We examine how the stories perform heterogeneity through the enactment of hope and the management of anxiety (analytical question 1). Moreover, we exemplify how the stories may have brought about change (analytical question 2), and how the author positions himself (analytical question 3). Finally, we explore the textual balancing between humility and paternalism in dealing with crying, the children, and death (analytical question 4).

Analytical question 1: How does the writing make room for heterogeneity?

Clinically, ALS is most often described as being extremely stressful, causing hopelessness, anxiety, despair, etc., leading to a defeatist approach from the medical establishment (Oliver 2006, pp. 19-24). For Hanne Stenmose, hopelessness is nurtured by what she sees as a nihilistic attitude among some health professionals. In her view, hope is part of imagining how to live with ALS, and it is not a matter of awaiting a miraculous cure, though hoping for that is never totally abandoned either.

Enacting hope

"False hopes can be the same as self-deception. That I think 'I'll never be on tracheostomy ventilation' or 'I'll keep walking'. Unless there is some kind of miracle, I know that's the way it goes. But to give up hope because of that, that's far out."

So the hope you have is not a hope of being cured? If you believed in a cure, would you call that self-deception? 
"I'm still hoping that it might be!"

Well, you can't rule anything out.

"No, you can't."

What I'm mostly hearing you say though, is that you're hoping to have a good life when you'll eventually need a ventilator?

"I also have a pretty clear idea of how things are going to be when I can't do this or that."

How do you want it to be?

"For instance, when it gets too hard for me to go to the bathroom, I want a catheter 'cause I don't want to spend an hour going to the bathroom. That way, I also won't need more than one personal assistant most of the time - maybe except from when I'm having a bath and need an extra person to towel me dry. But I can't see why it shouldn't be possible to lead a fairly good life anyway." (I am here every day, Story IV, Pt. 2)

Hanne Stenmose indicates that being allowed to hope is a precondition for thinking about and incorporating the future, no matter what it leads to.

While experiencing stressfulness might be true also for Hanne Stenmose, she also talks about the advantage of having been given more - and less stressful - time with her children.

You said that you can still contribute something positive to your family. What could that be?

"It's listening to what the kids are saying. Showing them how they can make the best of things if they run into problems. Of course they also need to figure it out for themselves, but I'm still allowed to show them the way. In general, I think it's important that there's at least one family member who is not stressed out and mostly in good spirits." (You are allowed to hope, Story III, Pt. 2)

"[...] I have been given the gift of being able to spend a lot of time at home. I'm here every day when they come home. And I have time to listen and to give them some input in their lives. And I actually think that is a gift." (I am here every day, Story IV, Pt. 4)

\section{Managing anxiety}

Hanne Stenmose is aware of the anxiety that her illness creates in her children. But again, she also sees the distressing situation as a possibility for them to learn and grow as she is able to teach her children how to come to terms with a human condition of life.

She has also talked to the kids about the time when she will inevitably need a permanent ventilator. They have seen pictures of people with ALS who are tracheostomized. "In a way they find it a little bit scary," says Hanne. But on the other hand, they understand why it will become necessary. (You are allowed to hope, Story III, Pt. 2)

Can having a mother with ALS also be a gift?

"N...yeah ... yes, in the way that the conditions of life have changed; that I have more time and more freedom; that they are also learning to be considerate." 
And also that they see all the physical things that are happening which they can be scared of - we have talked about that before, you used the expression 'that you create anxiety' - but they also benefit from that when things can't be changed? You can have your ALS in many different ways.

"Yes that's true. You can have it the positive way. You can teach the kids that if something is important to them, they need to fight for it."

Can you tell your children about that? How do you talk about it?

"Mads for instance is not good at doing his homework. But I've told him that 'If you want to be able to make your own decisions in life, you have to do something about it'. We know that some things come very easily to him, but he still needs to do his homework. He actually got his grades right before Christmas and even though his English teacher was furious with him, he still got an A. And it's the same in physics. But he still needs to understand why we want him to do his homework."

But do you think that has anything to do with you having ALS?

"Not really. On the other hand, if I don't do my homework, which is my exercises, I'll soon get stuck in my wheelchair."

Have you told him that?

"Yes, I've told him that I have homework twice a week - at the gym. Then I also exercise a bit at home. My personal assistants help me do it. I may not draw the parallels fully, but I still think I have developed a better technique for explaining things to them. And I don't think they are so terribly afraid of being close to me as some kids in puberty can be." (I am here every day, Story IV, Pt. 4)

In Hanne Stenmose's narrative, we witness an understanding of living with ALS that complements viewing the diagnosis as a lethal disease leaving no kind of hope. In the midst of a devastating disease, Hanne Stenmose seems to discover new opportunities: Time ("I've been given the gift of being able to spend a lot of time at home."); Being present ("I have time to listen and to give them some input in their lives."); Energy derived from hope (But to give up hope because of that, that's far out."); Becoming an empowering memory ("You can teach the kids that if something is important to them, they need to fight for it."). Concurrently, she does not repress the likeliness of dying from the disease, as will be demonstrated below.

\section{Analytical question 2: How does the story instigate change?}

The title of Story I, Worse than the diagnosis, refers to when the diagnosing neurologist broke the news making it clear that Hanne Stenmose would never be able to travel to Vietnam to show her adopted children their country of birth, and to meet the biologic mother of Mads. In fact, Hanne Stenmose actualizes precisely that dream, a realization playing a prominent role in story I.

"You must not deprive people of their dreams when you inform them of their diagnosis," Hanne said an hour ago, as she recounted how the neurologist back in 2008 made it clear, that she would never be able to travel to Vietnam carrying a diagnosis of ALS with her. And I realize what she meant as she went on: "The doctor took away my dream. In the situation, it was worse than the diagnosis." (Worse than the diagnosis, Story I, Pt. 1)

In the succeeding story the issue reappears. 
The diagnosing doctor, who said that she would not be able to travel to Vietnam with Claus and the children, Hanne has made to read the story too - and got a reply in return explaining why the doctor had said like that. Hanne still finds that the doctor made a mistake not keeping the possibility open. At the same time she says it "isn't on top of my mind that much" any longer. (Not only the end of the world, Story II, Pt. 4)

A mitigation of a traumatizing event has seemingly occurred. Possibly, the gravity of the experience has been altered by the process of storytelling. When the memory of the incident became a story, present reality is reformed. It can be viewed as a change instigated by the dialogical interplay between story and narrators transforming into a succeeding story.

Changing communication opportunities

In the final interview, Hanne Stenmose explicitly reflects on effects with her family, personal assistants, and physiotherapist of reading her stories. She also considers what her own reading produces.

"I feel I have got a good help through these interviews. By giving them to new personal assistants to sort of getting an expression of how I am. And my own family has read them as well. One of my sisters-in-law has said 'What a salutary reading'. She got background knowledge about me, she stated. My physiotherapist also said it was a pleasant experience, as I usually don't speak that much when I lie having physiotherapy. Because, when I lie down, I snuffle even more. Actually, I feel it's a real good thing. I also use it myself to think through things."

So you can talk about them?

"Yes, but not just that. It's also a reading for contemplation.

When you read, it triggers new thoughts?

"Yes." (I am here every day, Story IV, Pt. 6)

Judging from these reflections, the stories are a tool to create insight with the people, whom Hanne Stenmose depends on. Personal assistants learn about her way of being, family members obtain a more profound understanding, and a storied text might substitute conversation, compensating increasing difficulties with speech ${ }^{4}$. The stories bring about a change of communication opportunities that potentially improves social and caring relations. In addition, reading her own story causes Hanne Stenmose to rethink what she has said, instigating new thoughts about the meaning of her words.

\section{Analytical question 3: How does the author position himself?}

In a passage in Story II, the author puts himself to the fore by presenting a flashback taking place during the interview.

The conversation I had this morning on the ferry from Aarhus to Sjællands Odde runs through the back of my mind while Hanne is talking about telling her story. I accidentally ran into a couple of acquaintances who took the opportunity just to be told the aim of the stories I do with people with ALS. The ferry was some 10 minutes from arriving at the port. (Not only the end of the world, Story II, Pt. 4) 
The reader then witnesses a dialogue in which the author tries to account for his research project.

- I'm examining whether a patient's narrative can be used in his or her rehabilitation. The patient is engaged in lots of treatment interactions in which his or her personality may almost disappear. Narrative may be a means of holding onto oneself as someone able to take action; and thereby also becoming part of the treatment surrounding that person - in the lines of assistive devices, surgery, social case work, etc.

- You mean like a sort of self-therapy, asked the male part of the couple?

- No, that's not really the correct term, I answered, but naturally the narrative does something to the person, and to those reading it. And thereby it reacts on the person anew.

- I guess you also have to measure if it works, he continued?

Hmm ... This was far from the first time I was asked some version of that question, and as usually I began rambling on, because I imagine the inquirer expects another type of answer than the one I'm going to give

- First of all, I want to show if it's possible to write such stories with a person with ALS throughout a year of rehabilitation. Whether it makes sense for the person and for the readers ...

At this moment, we were asked to descend to the car deck. If I had had the chance to continue, I would have said that succeeding in making something make sense can also be a way of measuring. (Not only the end of the world, Story II, Pt. 4)

\section{Story building}

The passage is a scene in a scene, positioned in time and space. We experience a flashback-time on board a ferry, and an interview-time inside Hanne Stenmose's home. In addition, a writingtime is indicated by the modality of the verbs - 'had had' and 'would have' in the closing sentence. Four characters are on stage: Hanne Stenmose, the interviewer/author/researcher and his two acquaintances.

The scene-building exhibits various positions of the author. He is paying attention to Hanne Stenmose, while secretly reliving a moment from earlier that day; he is reasoning about his project, while secretly feeling uncertainties. The disclosure of the emergence of such ambiguities allows the author to establish himself as a writer without superior knowledge. And by uniting scene, dialogue, informal voice, and digression the story as an author's construct becomes evident.

Analytical question 4: How does the author balance between humility and paternalism? Hanne Stenmose cried several times during each interview, but outspoken agony is almost absent in the stories. One reason is that elaborating on tears, the story easily risks seducing the reader to feel only sad. Another reason is that emotional lability - excessive crying and/or laughing - is a clinical symptom in many people with ALS. This is the case also for Hanne Stenmose, which is why demonstrative depiction of weeping may give a false impression of her spirits. Of course Hanne Stenmose experiences sorrow, but that is always just part of the story. Pointing out of sadness, or joy, would be one-sided and compromise heterogeneity. 


\section{Crying}

The issue of crying is represented four times in the complete narrative. First time is at the end of Story I and almost reluctantly, though the interview began with several minutes of crying.

Hanne says: "Sometimes when I'm lying in my bed, I discover that right now it doesn't feel like I have ALS. That's a great feeling."

She continues: "But I can't lift anything. That's shit. I can't pour myself a cup of tea. I think arms are harder to do without than legs."

Hanne does not begin to cry even though she has just told me something very tragic. When we began our conversation almost four hours ago, we had only spoken for ten seconds before her voice was stifled with sobs for several minutes.

"It's so frustrating. My facial expression does not correspond with how sad I am. It's the ALS that exaggerates my reactions," Hanne explains and illustrates the distance between inside and outside by first placing the right hand index finger one centimeter above the surface of the table and then raising it some 35 centimeters. Thirty-five excess centimeters of tears.

What were your thoughts about me when you began to cry?

"I thought that you were probably used to it." (Worse than the diagnosis, Story I, Pt. 5)

In Story II Hanne Stenmose's crying is mentioned twice in an observing rather than demonstrative style and tone.

Hanne's nephew has collected a sum for the treatment and her mother has contributed with 10,000 Danish kroner. "She is 86 years old ..." says Hanne and breaks off the sentence because she has to cry. It takes a couple of minutes. (Not only the end of the world, Story II, Pt. 1)

"She can see that he's still able to smile," says Hanne and says that Thea has "asked to see him again". Hanne's lips are trembling and we take a 30-second break. (Not only the end of the world, Story II, Pt. 3)

The fourth and final recording of crying appears further ahead in Story II, prompting the author to disclose and discuss his emotional state, and to reflect upon what the crying is about.

When she is no longer able to go to bed unassisted she wants professional help. "But I don't want to go to bed at 9:30," she proclaims. Maybe they can brush her teeth and make her ready, then she can sit in her bathrobe until it is bedtime, she muses.

Again tears are approaching, but remain on the verge.

How do I feel about her crying? Is it unpleasant? Every time she cries, I say something to make her understand - feel - that I don't mind her crying. But is it true? Must I put on my professional face and remain unaffected by someone else's grief?

And what is lability anyway? Crying lability? It sounds like a disease.

What if we see it like this: Hanne cries exactly at the right time. Right when it hurts most. Many of us are good at hiding our tears, even the tears we cry inside, even to ourselves. Is that always a good quality for the person and for the surroundings? Maybe lability can be seen as the intensified ability to feel ones 
soft spots? An especially sensitive radar zooming in on possible dangers; a mine detector. (Not only the end of the world, Story II, Pt. 5)

\section{Leaving children}

A subject charged with emotion is the children. When talking about them, Hanne Stenmose would most often be moved (to tears), a sensation easily spread to the interviewer. Frequently, a sense of imminent despair would be present, but only as one of more coexisting realities of Hanne Stenmose's existence. An ambiguity represented by textually aligning everyday life trivialities with matters of sorrow.

The door to the entry hall swings open and two school bags are thrown onto the floor. It is Thea and her friend Michala. They are talking about the snow lasagna they have made on their way home. Snow lasagna? They explain the recipe to us as if it were the most natural thing, but then realize that there are things grown ups just don't get. The girls whirl into Thea's room, but not without making a detour to the cookie tin on the coffee table. It keeps Hanne's crisp homemade pepper cookies.

"We have told Thea and Mads that I have a disease which will eventually take away my ability to walk. And that I'll need help to breathe. But I have also told them that "I intend to see you grow up and become adults"."

Hanne says Thea will sometimes cry at school if she finds she did not get to say properly goodbye before she left. When that happens, she is usually allowed to run back home and start over. (Worse than the diagnosis, Story I, Pt. 5)

Thea's childlike joy and fantasy is exciting, imagining her running back home to repeat her goodbye is heartbreaking. A gamut of emotions coexist.

Death

When writing about death the text similarly aims at avoiding emotionalism, still capturing the unfathomable.

Today, Hanne is dressed in a bluish woolen dress, which makes you feel warm just by looking at it. A pair of black knit legwarmers keeps away the cold draft from the floor. It is January 4, 2011, 364 days have passed since the first interview, and it does not feel wrong to talk about the future.

Do you ever think about death?

"Yes, of course."

What do you think?

"That it's something we all know will come eventually. And I have sat down and written down how I want things to be with regard to the ventilator and how I want it turned off; and I have also thought about how I want my funeral to be; and I have written down that I don't want people to sing "Always dauntless when you leave", because I hate that song." 5

What would you want instead?

"'" In the East the sun rises"." 6

Yes, that's a beautiful hymn.

"And then I have written that I would like them to play "Tears in Heaven" by Eric Clapton.

"Tears in Heaven", I see. (I am here every day, Story IV, Pt. 1) 
But when you can't use your eyes anymore, then you won't be here anymore?

"No," says Hanne with a sorrow in her voice which seems to beg for forgiveness for her not being capable of living like that. (I am here every day, Story IV, Pt. 2)

The awareness of death has been present in all interviews as the medically likely end of the diagnosis ALS, not as a personal ending. It is an essence beyond words that you can only approach in writing. It is as if there is not much one really can or should say about not being here.

\section{Discussion}

Our discussion concerns three issues. Firstly, we consider the outcome of an analysis based on concepts of true writing. Secondly, to expand the notion of 'thinking with' stories, we deliberate on how the crafting of a story might be comprehended as an analytical process. And thirdly, we outline some concerns regarding the moral implications of performing stories publicly.

\section{True writing analysis}

We have analyzed how a non-fictitious personal public story can meet requirements for Heterogeneity, Sensitivity, Transparency, and Reflexivity, avoiding Emotionalism, Neutrality, and Superior Knowledge. Through representations of Enacting Hope, Managing Anxiety, Changing Communication Opportunities, Story Building, Crying, Leaving Children, and Death, we have examined whether textual authenticity have been performed.

The overall aim was to study how journalistic narrative may produce complementary insight. To assess the pertinence and sufficiency of the analytical strategy, we summarize what we regard as possible complementary knowledge in the selected excerpts from Hanne Stenmose's narrative:

- Hope is a multifaceted phenomenon.

- Hope is necessary to live.

- Hope is never abandoned.

- The fear of leaving one's children is accompanied by an encouragement to become an empowering memory.

- Becoming textually a story renews relations with family and may affect interactions with health professionals.

- Positioning author and characters in time and space renders the story transparent, allowing the reader to review the construction of story.

- Explicating subjectivity as part of the authoring grants equal narrative importance to all characters.

- Joy co-exists with despair.

- Death is uncommunicative.

These sentences could be categorized as outcomes concerning either content or form. Hope, Fear, Joy, and Death are about what we have learned; Becoming, Positioning, and Explicating are about how we have learned. Nevertheless, it would compromise a basic idea of complementary narrative to deduce such a distinction, because what the text says depends on how it is written. It is the self-aware authorial textual posture that produces the insights regarding hope, fear, joy, and death. 
Recapitulating our true writing scheme (Table 1), we find that the categories Change, Sensibility, Transparency, Reflexivity, Emotionalism, Neutrality, and Superior Knowledge have been fruitful to create an analytical 'how-to-write' that produces subjective otherness, i.e. Heterogeneity. In consequence, the analytical questions 1-4 should be viewed as overlapping and intertwined. All categories are in varying extent represented in each question. To make room for heterogeneity includes affording change, staying sensitive, allowing transparency, being reflexive, and avoiding emotionalism, neutrality, and superior knowledge; and vice versa.

Possibly, the analytical questions could have been more, or fewer, and in other wordings. The number must be weighed against practical feasibility, and the phrasing should be operational, but either way a sound analysis grounded in true writing concepts is the goal. We think our choices have been adequate and appropriate for this narrative, but future analysis of the other five chronicles in the overall study may sophisticate analytical questions. Those chronicles tell five different stories, which may give rise to modifications of the analytical strategy of the complementary journalistic narrative (National Rehabilitation Centre for Neuromuscular Diseases, 2011)

\section{Thinking with}

When we claim that writing as shown in this article can be a researching activity, the conversion of transcript - together with other accumulated impressions and expressions such as feelings and sensations, memory, recollections and observational notes - into a story should be comprehended as part of an analytical process, which is interpreted as narrative by the synthesizing of form and content. Furthermore, it is a continuing process comprising readers' reception of the narrative as an embodied acquisition, invoking new stories in a continued cycle of 'story in the making'. In this view, we would argue that the story must be read in full to fulfill itself and to answer the questions: What do I make of it? How does it affect me? (Charon, 2006).

The stories in the ongoing study of journalistic narrative as patient involvement in professional health rehabilitation are about something, which the stories deal with otherwise. Main themes such as stemcell therapy, hope, crying, the children, being a parent, death, etc., refer to an 'about something', while in narrative reading the stories seem concerned with what is not articulated and phrased, because it 'exists' as inexpressible. In the case of the stories with Hanne Stenmose, we translate our subjective narrative reading as: I heal partially; I reconcile gracefully with my ALS; I become an empowering memory to my children.

Reading the stories with Hanne Stenmose, we are informed intellectually and emotionally that ALS is a condition that cannot be comprehended as an entity detached from the person's identity and daily life. ALS is a transformative state of living, where you repeatedly lose and gain and lose. The stories are not prime samples of how to cope with the disease. They can be said to solve subjectively and temporarily some of the communicative purposes and needs of the individual person with ALS, but they never resolve by prescribing how to live with ALS, paraphrasing Arthur Frank: "This balance solves but never resolves; it is never a finalized solution. What is solved is how to keep the tension within the bounds of dialogue - to keep dialogue open." (Frank, 2004a, p. 133)

Our study can be seen as a supplement to the discussion about dialogue and heteroglossia of the research interview (Tanggaard, 2009). The findings, we think, clarify that there are multiple 
dimensions of subjective knowledge as well as diverse authorities to articulate that knowledge. An assumption corresponding with health research theorists Jensen, Mattingly, and Throop stating: "Theories of the self, and in particular narrative theories and representations of acted lives, can bring to light the highly charged nature of moments that might otherwise seem undramatic, just the way things are. They can help us to consider the mysteries of everyday experience and the paradox of emotion." (Mattingly, Jensen and Throop, 2009, p. 7).

\section{Moral implications}

Speaking in public is definitional of journalism, and usually narrators are non-anonymous, as is the case with Hanne Stenmose (Adam, 2006). A protagonist will bear in mind the consequences of his or her public statements: Hanne Stenmose explicitly withholds what she is talking to a psychologist about regarding her relation with her husband and children (I am here every day, part 6). For "loyalty" reasons, she terms it. We do not see this as an inadequacy, as a lack of relevant information. Rather, the absence of privacy reinforces what you are prepared to answer for publicly, constituting a socially true personal knowledge.

Still, a moral dilemma of both protecting and exposing the interviewee arises when you perform stories publicly. On one hand, you should prevent the person from saying more than he or she can abide by in public; you must avoid that the intimate conversation, which may touch upon painful memories, insensibly turns into pitiable concern; you should constantly remember the difference between friendship and inter-human recognition. On the other hand, you need to endure unforeseeable spans of time passing silently, waiting in patience for the person to express him or herself; you have to find courage to ask about things that worry or hurt. The journalist must dig deep at the same time keeping his distance. Understand in depth but not pity. Nor admire.

Some journalists suggest the term empathic professionalism to describe the quality with which practitioners of narrative journalism need to supplement their "old-fashioned critical journalism" (Dalviken 2005, p. 116). They talk about 'distanced closeness'. Harrington finds that the journalist must give up the professions' usually rather cynical approach of not accepting anything at face value, not to take a naive approach but to nourish the fundamental human kindness that is necessary to understand another person: "... a wise person must learn to lose your innocence but not your hope." (Harrington, 1997, p. xxvi)

Steinar Kvale has warned against dialogic empathy acting as a social lubricant that causes an intended or unintended intimacy (Kvale, 2006). In either case, irrelevant information may be hidden behind an aura of genuine intimacy, serving as a manipulative cover, coaxing people to make confessions that can be used to generate money in the market for stories about real life. But warm and friendly reciprocity might suppress truths that unfold in disagreements and in relationships of conflict. Dialogic interviews based on mutuality and solidarity between researcher and study subject are not good and freeing per se, Kvale says, calling for empirical studies of the dynamics of power and how they influence the knowledge produced in various interview forms. He advocates a more transparent rendition of the interaction between interviewer and interviewee.

The complementary journalistic narrative is an attempt, we find, to reconcile being transparently confrontational and empathically dialogic at the same time, by insisting on explicit textual reflexivity regarding how the author positions himself. 
Narratives are equally well-suited to deception and liberation, Yannis Gabriel asserts (Gabriel 2004). They represent narrative raw materials processed for the purpose of articulating and communicating facts as experience rather than information, he says. There exists an implicit underlying contract concerning allowable exaggerations, omissions and deviations from verifiable realities; the narrator enjoys the privilege of the listener suspending his suspicions in return for a story that conveys authenticity and meaningfulness. Gabriel believes that researchers - and narrative journalists we would include - have a special responsibility to examine the origin of personal experience in order to trace blind spots, illusions and selfdeception. Narrative as qualified communication must be approached with the same scepticism and suspicion as all other forms of authoritative knowledge. The methodological obligation to pose critical questions is not of less importance to complementary journalistic narrative writing.

\section{Conclusion}

We conclude that narrative journalism might add on to social science by supplementing its ways of knowing. It can be viewed as a method of research producing knowledge about being and becoming a subject. In the case of Hanne Stenmose, we have learned about hope, fear, joy, and death through her becoming a story in which authorial position and subjectivity are explicated. In that way narrative journalism is a method of inquiry both pointing to an otherness of the individual and the contextual construction of selves.

We view the subjective narrative knowledge produced as complementary to diagnostic facts of the scientific medical textbooks and clinical traditions, which are inclined and obliged to look for what can be recognized as generalizable and systematizable. Serious illness attacks one's sense of being other than the illness, and because they must look for recognizability to be systematized, professionals tend to see the self as diseased. We suggest that the stories mirror this endangered otherness of the self, exposing an asymmetry between inner experience and external judgment. Consequently, such stories might be a method of patient involvement complementary to classic dialogical instruments like user questionnaires, patient advisory boards or citizen hearings. Journalistic narrative seems to capture dimensions of the subjective everyday life in different contexts considered by the protagonist to be of utmost importance.

In conclusion, narrative journalism may be one way of writing science about what it means to be human taking into the account the complementary understanding of that meaning.

\section{Acknowledgements}

The Danish National Rehabilitation Centre for Neuromuscular Diseases facilitated access to participants in the study of journalistic narrative as patient involvement. The study is part of a $\mathrm{PhD}$ project funded by the Danish Neuromuscular Patient Association and the Danish Ministry of Science, Technology and Innovation. A draft version of this article was discussed at a seminar with the research unit Health, Man and Society, Institute of Public Health, University of Southern Denmark. Constructive criticism from an anonymous reviewer has helped us explicate analytical issues. Mrs. Annette Mahoney translated excerpts of journalistic stories and proofread the manuscript. 


\section{Notes}

1) According to the Danish quantum physicist Niels Bohr a method of observation might affect the object and/or the observer in a way undeterminable by that method. Bohr argued that a principle of complementary description was needed to understand life, in particular man (Favrholdt, 2010, p. 185 and p. 301-302. See also Bohr, 1985).

2) Arthur Frank builds on the Bakhtinian construct of 'Unfinalizability' (Frank, 2005), and the Lévinasian idea about Alterity (Frank, 2004a. Irvine, 2005).

3) 'True' in the sense genuine or good writing, not as writing the truth.

4) Ultimately, the ALS patient loses the ability to speak with the voice.

5) Altid frejdig når du går; translates app.: Always dauntless when you leave. Danish hymn traditionally sung at funerals.

6) I Østen stiger solen op; translates app.: In the East the sun rises. Popular Danish morning hymn, taught in most preschool classes.

\section{References}

Adam, G.S. (2006). Notes Towards A Definition of Journalism. In G.S. Adam and R.P. Clark (Ed.), Journalism: The Democratic Craft. New York and Oxford: Oxford University Press.

Bohr, N. (1985). Kundskabens enhed [The unity of knowledge]. In N. Bohr, Naturbeskrivelse og menneskelig erkendelse [Description of nature and human cognition]. Copenhagen: Rhodos.

Charon, R. (2006). Close Reading. In R. Charon, Narrative Medicine: honoring the stories of illness. New York: Oxford University Press.

Dalviken, L. (2005). Fortællende journalistik i Norden [Narrative journalism in the Nordic countries]. Aarhus: Ajour.

Denzin, N.K. (1997). The New Journalism. In N.K. Denzin, Interpretive Ethnography: Ethnographic Practices for the 21st century. California: Sage Publications.

Denzin, N.K. (2000): The Practices and Politics of Interpretation. In N.K. Denzin and Y.S. Lincoln (Ed.), Handbook of Qualitative Research, 2nd ed. California: Sage Publications.

Denzin, N.K. (2003). Performance Ethnography: Critical Pedagogy and the Politics of Culture. California: Sage Publications.

Favrholdt, D. (2010). Filosoffen Niels Bohr [The philosopher Niels Bohr]. Copenhagen: Informations Forlag.

Frank, A.W. (2004a). The Renewal of Generosity: Illness, Medicine, and How to Live. Chicago: The University of Chicago Press.

Frank, A.W. (2004b). After Methods, the Story: From Incongruity to Truth in Qualitative Research. Qualitative Health Research, 14 (3): 430-440. 
Frank, A.W. (2005). What Is Dialogical Research, and Why Should We Do It? Qualitative Health Research, 15 (7): 964-974.

Gabriel, Y. (2004). The voice of experience and the voice of the expert - can they speak to each other? In B. Hurwitz and T. Greenhalgh and V. Skultans (Ed.), Narrative Research in Health and Illness. Oxford: Blackwell Publishing, BMJ Books.

Harrington, W. (1997). A Writer's Essay: Seeking the Extraordinary in the Ordinary. In W. Harrington (Ed.), Intimate Journalism: The Art and Craft of Reporting Everyday Life. California: Sage Publications.

Irvine, C.A. (2005). The Other Side of Silence: Levinas, Medicine, and Literature. Literature and Medicine, 1 (24): 8-18.

Jeppesen, J. (2011). Hanne Stenmoses fortælling [Hanne Stenmose's narrative] [Internet]. Aarhus: The National Rehabilitation Centre for Neuromuscular Diseases. Available online at: http://www.rcfm.dk/forskning-udvikling/rehabilitering-som-fortaelling/hanne-stenmose/, accessed 1 March 2011.

Jørgensen, J.C. (2007). Journalistik med stil. Fra klassiske nyheder til fortælling [Journalism with style. From classic news to narrative]. Aarhus: Ajour.

Kramer, M. and Call, W. (Ed.). (2007). Telling True Stories: A nonfiction writers' guide from the Nieman Foundation at Harvard University. New York: Plume, Penguin Group.

Kvale, S (2006). Dominance Through Interviews and Dialogues. Qualitative Inquiry, 12 (3): 480500 .

Mattingly, C.F. and Jensen, U.J. and Throop, C.J. (2009). Narrative, Self, and Social Practice. In U.J. Jensen and C.F. Mattingly (Ed.), Narrative, Self and Social Practice. Aarhus: Philosophia Press.

National Rehabilitation Centre for Neuromuscular Diseases (2011). Rehabilitering som fortælling. Historier om hverdag, helbred og rehabilitering med sygdommen ALS [Rehabilitation as narrative. Stories on everyday life, health and rehabilitation with the disease amyotrophic lateral sclerosis] [Internet]. Aarhus: The National Rehabilitation Centre for Neuromuscular Diseases. Available online at: http://www.rcfm.dk/forskningudvikling/rehabilitering-som-fortaelling/, accessed 13 July, 2011.

Oliver, D. (2006). Palliative care. In D. Oliver and G. D. Borasio and D. Walsh (Ed.), Palliative Care in Amyotrophic Lateral Sclerosis (2nd ed.). Oxford: Oxford University Press.

Richardson, L. and St. Pierre, E.A. (2005): Writing: A method of inquiry. In N.K. Denzin and Y.S. Lincoln (Ed.), Handbook of Qualitative Research (3rd ed.). California: Sage Publications.

Tanggaard, L. (2009). The Research Interview as a Dialogical Context for the Production of Social Life and Personal Narratives. Qualitative Inquiry, 9 (15): 1498-1515. 
Tanggaard, L. and Brinkmann, S. (2010). Formidling af kvalitativ forskning [The communication of qualitative research]. In S. Brinkmann and L. Tanggaard (Ed.), Kvalitative metoder. En Grundbog [Qualitative methods. A textbook] Copenhagen: Hans Reitzels Forlag.

Thorsen, N. (2003). Klangen af et menneske. Om at spørge godt, lytte rigtigt og finde sit eget sprog [The ring of a human being. On skilful asking, competent listening, and finding one's own language]. Aarhus: Ajour.

\section{Authors}

Jørgen Jeppesen is a PhD scholar in the Institute of Public Health at the University of Southern Denmark. Helle Ploug Hansen is a professor in the same institute. Email of corresponding author (Jeppesen): jjeppesen@health.sdu.dk 